\title{
PEDAGOGICAL SUPPORT OF STUDENTS IN DIGITAL EDUCATION
}

\author{
Indira Salpykova $^{1 *}$, Almira Garifullina $^{2}$, Seimbika Bichurina $^{3}$, Natalya Koletvinova ${ }^{4}$ \\ ${ }^{1}$ Candidate of pedagogics, Kazan (Volga region) Federal University, Kremlyovskaya Street, 18, \\ Kazan, Russia, E-mail: indimar24@mail.ru \\ ${ }^{2}$ Candidate of pedagogics, Kazan (Volga region) Federal University, Kremlyovskaya Street, 18, \\ Kazan, Russia, E-mail: alm.garifullina2012@yandex.ru \\ ${ }^{3}$ Candidate of pedagogics, Kazan (Volga region) Federal University, Kremlyovskaya Street, 18, \\ Kazan, Russia, E-mail:bichurina@yandex.ru \\ ${ }^{4}$ Doctor of pedagogy, Kazan (Volga region) Federal University, Kremlyovskaya Street, 18, Kazan, \\ Russia, E-mail: koletvinova_nd@mail.ru
}

\begin{abstract}
This article is devoted to finding a solution to the problem of improving the quality of the process of professional training of students in e-learning. Modernization of higher education plays a major role in the modernization of society. Digitalization should become a tool for modernizing higher education in the era of the Fourth Industrial Revolution.

The main purpose of the educational process in Kazan Federal University (KFU) is the preparation the highly qualified staff for different fields of Volga Federal District. The content bases of the Russian high education are conceptualized in normative legal documents, federal state educational standards. However, the modernization process of the Russian education requires improvements in the student's level of preparation by the introduction of e-learning technologies. According to the Russian and foreign data, e-learning and the phenomenon of assisting the process of preparing students became the subject of study only recent decades. Numerous studies of the last years are demonstrating the need for revision the educational system of high school and creating special conditions for the organizational and pedagogical support of the process of the professional preparation of the students in an e-learning.

In the view of the foregoing, the purposes of research are development and approbation the model of organized pedagogical support of the preparatory process in an e-learning. The methodological bases of the research were: competence, personality-oriented, systemic, activity-oriented, structural-functional and system-diagnostic approach. Research methods: analysis of theoretical and methodological literature, normative programmatic documentation; pedagogical modeling, methods of generalization and systematization of empirical data.

In the course of the study, the authors analyzed theoretical ideas in the field of professional competence, implementation and the possibilities of e-learning, the phenomenon of support. The model of pedagogical support of the process of preparing students in the context of e-learning is presented by targeted, meaningful, activity oriented, and evaluation productive components. Its content was based on the electronic course "Theater pedagogy" in the context of the use of the Learning Management System (LMS) Moodle (Modular Object-Oriented Dynamic Learning Environment). As a result of the study, the directions of the pedagogical support of the students of the Kazan Federal University in an e-learning are determined: organized-methodological, educational, analytical. The effectiveness of the proposed model in the context of forming the professional competencies of the students is proved.
\end{abstract}

Keywords: education, University, pedagogical support, model, e-learning, Moodle system, student learning process at the university 


\section{INTRODUCTION}

\subsection{Background}

The problem of digitalization of Russia in the XXI century is becoming particularly relevant at the present time. The new era of Informatization and globalization in education requires its modernization and the application of new approaches to the organizational activities of Higher education. The creation of digital economy requires an appropriate orientation of the education system, training of people who use modern digital technologies in their activities. Distance learning gains the popularity every day, significantly expanding the teaching and learning space and allowing the students to learn inter-faculty university programs in depth. The new "digitalization wave" (Koroleva, 2016) is associated with the adoption of the national project Education, in which a series of large-scale projects is planned. Federal projects such as Digital Educational Environment and Teacher of the Future are designed to create opportunities for eeducation and learning, as well as improve training of future teachers. Improving the effectiveness of students ' training is possible through the use of e-learning. The relevance of the problem is determined by the need to improve methods of teaching artistic and aesthetic disciplines for students-future teachers of preschool educational organizations and the need to develop methods and forms of using distance educational technologies in this process. Virtual environment Moodle has become very popular among educators around the world as a means of creating dynamic websites for students.

\subsection{Explore Importance of the Problem}

A certain role in mastering the disciplines of artistic and aesthetic orientation is played by the process of forming the competencies that a future teacher of a preschool educational institution should possess, as indicated in the Federal state standard of higher professional education 3++ in the training direction 44.03.01 "Pedagogical education" for bachelors. Student majoring in Teacher-training Education is to acquire the following competencies: knowledge of methods and means of obtaining, storing, processing information; computer skills as a means of information management; ability to work with information in global computer networks; readiness to apply modern methods and technologies, including information, to ensure the quality of the educational process at a particular educational level of a particular educational institution; ability to use the resources of the educational environment, including IT-resources, to ensure the quality of the educational process. Often in the process of teaching artistic and aesthetic disciplines, questions arise about the combination of traditional teaching methods with the use of distance technologies. Building the indicated competencies implies the multi-level structure of the information and communication space as part of the academic environment of the university. Virtual environment Moodle has become very popular among educators around the world as a means of creating dynamic websites for students. Taking into account the huge educational potential of art objects in the process of forming the spiritual culture of the individual, we have identified a set of measures related to the trends in the development of teacher education in the multilevel training system at the Kazan (Volga) Federal University (KFU). Pedagogical support of students in the conditions of using the learning management system (SMO) Moodle (modular object-oriented dynamic learning environment) is implemented by research works carried out at KFU in the framework of the project "Teacher of the XXI century", included in the priority interdisciplinary research areas of development. Contradictions allowed us to identify the problem of research - what should be the pedagogical support of the process of professional training of students, carried out in an e-learning environment, so that it is possible to increase the effectiveness of training. We believe that the electronic course "Theater pedagogy" Organization Brand using the Moodle (Modular Object-Oriented Dynamic Learning Environment) Learning Management System (LMS) will increase the motivation of distance learning post-graduate students to work independently in the context of building professional competitions.

\subsection{Status of a Problem}

Research shows that the prerequisites for solving this problem have been created. The research dedicated to the Russian history, Theory and Practice of Distance Education is found in the works of (Gromkova, 1993 and Zimakova, 1995). The improvement of distance learning by means of IT, distance educational technologies were considered by (Loginov, 2008 and Telesheva, 2003). The implementation problems and e-learning potential were investigated by (Ustyugova, 2010; Deborah Keyek-Franssen, 2018). Information competence was studied by (Polat, Bukharkina, 2011; Vlasova, et al., 2015). 
The need for a manager to accompany studies at a university in terms of using information and communication technologies is indicated in various works (Romanova, et al., 2017; lbragimov, 2018). The following authors considered the relevant ideas in their research work: systematic approach (Lebedev, 2006; Mitsel, 2006, etc.); the activity approach highlighted (Galionova, 2009; Zakharova, 2009, etc.); structural and functional approach (Yakovlev, 2010).

\subsection{Hypothesis}

The process at the university in the context of e-learning will be successful in developing and implementing a structurally functional model of pedagogical support, including targeted, meaningful, operational-activity and assessment components and productive interaction of all subjects of the educational process: students and teachers.

\section{MATERIALS AND METHODS}

\subsection{Research Aim}

The analysis of theoretical works and practical activity in the framework of the developed problem showed that so far the issues of organizational and pedagogical support of raining learning, carried out in the context of e-learning, has been studied insufficiently in trams of scientific knowledge and practical activity. This allowed us to formulate the goal of the study: to develop a structural and functional model of pedagogical support for the training via the Moodle system.

\subsection{Theoretical and Empirical Methods}

To achieve the goal of the study, the following methods were applied: analysis of theoretical sources, analysis; synthesis; concretization; generalization; method of analogies; pedagogical modeling.

\subsection{Research Site}

The study was conducted at the Institute of psychology and education of Kazan Federal University, at the Department of preschool education. The study of the problem was carried out in three stages.

\section{RESULTS}

\subsection{Model Structure}

Virtual environment Moodle has become very popular among educators around the world as a means of creating dynamic websites for students. Analyzing the didactic potential of electronic educational resources, it seems to us possible to highlight the positive aspects of its use in the process of organizational and pedagogical support of students (Table 1).

\begin{tabular}{|c|c|}
\hline Organizational forms & Potential Of Distance Learning Courses \\
\hline Lecture & Increasing The Information Volume Of Educational Material \\
\hline Seminar, Practice Class & Control Of Practical Tasks, Tests, Essays, Etc. \\
\hline Independent Work & Addition Of Web 2.0 Resources With Results Of Our Own \\
Research
\end{tabular}

Table 1. The electronic resources potential in organizational and pedagogical support

Generally speaking, the use of the Moodle learning management system allows ensuring confidentiality of training; compliance with the principles of successful learning.

\subsection{Structural Model of Organizational support of Training via the Moodle System}

Teaching artistic and aesthetic disciplines to students of pedagogical specialties has its own specifics, it is primarily associated with the features of professional training in preschool educational organizations. Students should have not only theoretical knowledge in the field of national and world culture and art, but also practical skills in applying the technology of musical education in the daily life of kindergarten. The main components of the model are the target, content, functional and assessment blocks. The purpose and objectives of the discipline have been determined in accordance with a set of competencies identified in Federal State Education Standard of Higher Education 
Goals: improving the effectiveness of the process of training students in e-learning in accordance with the goals formed by the competencies of the discipline.

Tasks: formation of theoretical knowledge and practical skills of students-future teachers in the organization of theatrical activities in the pre-University, as well as in the form of theatrical techniques as a method of increasing the level of effectiveness of educational pedagogical influence.

Organizational support of training via the Moodle system

Content component

Functional component: presentation of a complex of forms, methods, training aids.
Assessment component: performance indicators of the education process
- development and implementation of an electronic course, development of an electronic educational and methodical complex of design in the Moodle system;

- electronic educational and methodological complex of the discipline;

stimulating the activity of independent activity when performing tasks, tests, etc.);

automated processes for monitoring progress and recording results; development of individual student curricula.

Course (discipline) "Theater pedagogy»:

Module 1

Lectures: Specific foundations of theater as an art form. Historical aspect. Modern theatrical art, genres, types, syncretic and synthetic theatrical performance $\rightarrow$ Presentation $\rightarrow$ Forum- (ofline-) or Chat Lessons (online-) $\rightarrow$ Glossary $\rightarrow$ Tasks for control $\rightarrow$ Forum- (off-line).

Module 2.

Lectures: Theater pedagogy and its role in the education of preschool children $\rightarrow$ Forum(ofline-) or chat classes (online-) $\rightarrow$ Glossary $2 \rightarrow$ Audio and video files $\rightarrow$ exchange messages with the teacher $\rightarrow$ Assignments for control. $\rightarrow$ Forum- (off-line).

Module 3. Lectures: Organization of theatrical activities in pre-school education institutions.Forum- (ofline-) or chat classes (online-) $\rightarrow$ Glossary $4 \rightarrow$ Audio and video files $\rightarrow$ Assignments for monitoring $\rightarrow$ exchanging messages with a teacher $\rightarrow$ Intermediate test $\rightarrow$ Final test $\rightarrow$ Consultation (full-time) or part-time) $\rightarrow$ Credits (creative project defense).

Organizational and methodological support of the process: the curriculum of the discipline, lecture texts, presentations.

Educational and methodological recommendations for independent work of students: topics and tasks for independent work, guidelines, recommendations for implementation.

Information support: "Forum", “Test", 


\begin{tabular}{|l|l|}
\hline $\begin{array}{c}\text { "Glossary", "Lecture", } \\
\text { "Resource", } \\
\text { "Questionnaire", "Task", a list of basic and } \\
\text { recommended literature; control and } \\
\text { assessment materials ton-line tests, } \\
\text { questionnaires, control questions). } \\
\text { Quality of material acquisition; the formation } \\
\text { of motivation for the educational activities, } \\
\text { contributing to the strengthening of } \\
\text { intellectually-motivating motives; satisfaction } \\
\text { with educational and professional activities; } \\
\text { engagement in the educational process. }\end{array}$ \\
\hline
\end{tabular}

Table 2. Structural model of organizational and pedagogical support of training in the Moodle system

A modular approach provided flexibility and openness to the curriculum. In the preparation and conducting the classes, the following set of elements of the course were used: "Forum", "Test", "Resource", "Glossary", "Lecture", "Questionnaire", "Task".

It is important to note that the Moodle training system provides the ability to track and assess independent tasks, the learning outcomes. Each student can ask the on-going questions, both organizational and those concerning the discipline. In accordance with this, the design of organizational support of the training of students, acquires a research and practice-transformative character and becomes the subject of mastering the discipline "Theater pedagogy".

Thus, it can be assumed that training future teachers of preschool educational organizations by applying the Learning Management System (LMS) Moodle, via the given structure and functional model helps to improve the quality of knowledge of students of the Designing "Theatre pedagogy", determine the formation of motivation for educational activities, as well as the engaging in the educational process by ensuring continuity and openness of the preparation process.

\section{DISCUSSIONS}

To implement e-learning in the learning process of students, the readiness and ability of teachers to use information technology is necessary.

We can see the implementation of these conditions especially clearly now, during the COVID-19 pandemic, when all educational institutions switched to distance learning, which allowed continuing the educational process at all levels of education.

The use of information technologies can become a factor that stimulates the development of professional knowledge and competencies through the assimilation of the content of training courses, in our study of the course "Theater pedagogy". Distance learning allowed students and teachers to interact indirectly, at a distance.

\section{CONCLUSION}

It is established that the proposed model of pedagogical support for students thanks to the unity of interrelated target, content, functional and assessment components contributes to the formation of educational activity motivation, engagement in the educational process by ensuring continuity, openness of the preparation and providing for the subject position of a student. The result of testing the structural model of the organizational support of students through e-learning is the development by the team of authors of the Designing a "Theatre pedagogy", preschool institution course using the Learning Management System (LMS) Moodle (Modular Object-Oriented Dynamic Learning Environment). The structural model of organizational support can be used in organizing the process students of various majors and specialties of the university, provided that the necessary adjustments are made depending on the academic program's specifics.

\section{ACKNOWLEDGMENTS}

The work is performed according to the Russian Government Program of Competitive Growth of Kazan Federal University 


\section{REFERENCE LIST}

Zimakov, I.E. (1995) Part-time education in modern Russia. Higher Education in Russia. (1). 73-79.

Vlasova, V. K., Kirilova, G. I., \& Masalimova, A. R. (2015). Information and Logistic Foundations of Pedagogical Education Design and Content Education. Review of European Studies. 4(7), 54-58.

Gromkova, M.T. (1993). Pedagogical foundations of adult education. Moscow: Publishing House of Moscow Artists Academy, 164.

Ibragimov, G.I. (2018). Transformational processes in the theory and practice of learning in the context of the formation of the information knowledge space. Professional and Higher Education: Challenges and Development prospects. Moscow: Econ-inform, 275

Koroleva, D.O., Havenson, T.E., Lukina, A.A. (2019). Get stuck in a jump: how preschool and school education goes to digital. Head Teacher. (8), 63.

Lebedev O.E. (2004). Management of educational systems: manual for universities. Moscow: University book, 256, 2004.

Loginov, S.P. (2008). Foreign experience in the application of information and communication technologies in distance learning: history and prospects. Bulletin of Moscow City Pedagogical University. Series: Informatics and Informatization of Education. (16), 136-140.

Mitzel, A.A. (2006). Distance education as a component of the process of forming a single educational space. Moscow: Open Education, 2, 59-65.

Romanova, E.V., Perevozchikova, L.S., Ershov, B.A. (2017). The Lifestyle of the Human Being in the Information Society. 3rd International Conference on Advances in Education and Social Sciences Proceedings of ADVED Pp. 950-954.

Polat, E.S., Bukharkina, M.Yu., Moiseeva, M.Yu., Petrov, A.E. (2011). New pedagogical and information technologies in the education system. Moscow: Academy, 272.

Polat E.S. (2006). Pedagogical technologies of distance learning: textbook. Moscow: Academy, 400.

Telesheva, N.F. (2003). Improving the effectiveness of professional education of part-time students in the conditions of distance learning. PhD Thesis. Krasnoyarsk, 184.

Ustyugova V.N. (2010). Moodle distance learning system: study guide. Kazan, 280.

Keyek-Franssen, D. (2018). Student Success Practices: from full-time to large-scale and vice versa. Moscow: Education Issues (4), 116-138.

Yakovlev, E.A. (2010). Tutoring as a pedagogical phenomenon. Modern Higher School: An Innovative Aspect, 4, 74-83. 